\title{
Mitigating preventable chronic disease: Progress report of the Cleveland Clinic's Lifestyle 180 program
}

Elizabeth HW Ricanati ${ }^{1}$, Mladen Golubić ${ }^{*}$, Dongsheng Yang $^{2}$, Leif Saager ${ }^{3}$, Edward J Mascha $^{2}$ and Michael F Roizen ${ }^{1}$

\begin{abstract}
Background: Poor lifestyle choices are key in development and progression of preventable chronic diseases. The purpose of the study was to design and test a program to mitigate the physical and fiscal consequences of chronic diseases.

Methods: Here we report the outcomes for 429 participants with one or more chronic conditions, including obesity, hypertension, hyperlipidemia and diabetes mellitus, many of whom had failed traditional disease management programs, who enrolled into a comprehensive lifestyle intervention. The Lifestyle 180 program integrates nutrition, physical activity and stress management interventions and was conducted at the Wellness Institute of the Cleveland Clinic, United States. An intensive 6 week immersion course, with 8 hours of group instruction per week, was followed by 3 follow-up, 4 hour-long sessions over the course of 6 months.

Results: Changes in biometric (weight, height, waist circumference, resting heart rate and blood pressure) and laboratory variables (fasting lipid panel, blood glucose, insulin, hemoglobin A1c, ultra sensitive C-reactive protein) at 6 months were compared with baseline (pre-post analysis). At week 30, biometric and laboratory data were available for 244 (57\%) and 299 (70\%) participants, respectively. These had a mean \pm SD reduction in weight ( $6.8 \pm 6.9 \mathrm{~kg}, \mathrm{P}<0.001)$, waist circumference $(6.1 \pm 7.3 \mathrm{~cm}, \mathrm{P}<0.001)$, glucose $(4.5 \pm 29.6 \mathrm{mg} / \mathrm{dL}$ or $0.25 \pm 1.64 \mathrm{mmol} / \mathrm{L}, \mathrm{P}=0.009)$, triglycerides $(26.4 \pm$ $58.5 \mathrm{mg} / \mathrm{dL}$ or $0.30 \pm 0.66 \mathrm{mmol} / \mathrm{L}, \mathrm{P}<0.001)$, low-density lipoprotein cholesterol (LDL) $(7.9 \pm 25.1 \mathrm{mg} / \mathrm{dL}$ or $0.2 \pm 0.65$ $\mathrm{mmol} / \mathrm{L}, \mathrm{P}<0.001)$, hemoglobin A1c (HgbA1c) $(0.20 \pm 0.64 \%, \mathrm{P}=0.001)$, insulin ( $3.8 \pm 11 \mathrm{microU} / \mathrm{ml}$ or $26.6 \pm 76.4 \mathrm{\rho mol}$, $P<0.001)$ and ultra sensitive C-reactive protein (US - CRP) $(0.9 \pm 4.8 \mathrm{mg} / \mathrm{dL}$ or $7.3 \pm 40.2 \mathrm{nmol} / \mathrm{L}, \mathrm{P}=0.012)$, an increase in mean high-density lipoprotein cholesterol (HDL) $(3.7 \pm 8.4 \mathrm{mg} / \mathrm{dL}$ or $0.1 \pm 0.22, \mathrm{P}<0.001)$, and decreased use of medications.
\end{abstract}

Conclusion: Implementation of a comprehensive lifestyle modification program among adults with common chronic conditions results in significant and clinically meaningful improvements in biometric and laboratory outcomes after 6 months.

Keywords: Lifestyle, Nutrition, Exercise, Stress Management, Chronic disease, Obesity, Hyperlipidemia, Hypertension, Diabetes

\footnotetext{
* Correspondence: golubim@ccf.org

${ }^{1}$ Wellness Institute, Cleveland Clinic, 1950 Richmond Road, TR2-341,

Lyndhurst, $\mathrm{OH}$ 44124, USA

Full list of author information is available at the end of the article
} 


\section{Background}

Interactions between lifestyle and genetic factors cause the development and progression of a spectrum of chronic conditions, including obesity, type 2 diabetes mellitus, hypertension, cardiovascular disease and several types of cancer. For some of these major causes of mortality, not only in Western societies but globally, more than $80 \%$ of attributable risks may be related to environmental, primarily lifestyle factors $[1,2]$. In a recent prospective study, participants who were successful in maintaining body mass index below 30 , not-smoking, exercising about $3.5 \mathrm{hrs}$ per week and eating mostly plant-based diets with limited amount of meat had a $78 \%$ lower risk of developing chronic disease than those without a healthy lifestyle factor [3]. It is, therefore, not surprising that health-promoting lifestyle behaviors are prominently included in practice guidelines for prevention or management of most chronic conditions [4]. Several groups of investigators have successfully used comprehensive lifestyle interventions for treatment of chronic conditions, including coronary artery disease, metabolic syndrome and type 2 diabetes mellitus [5-9].

Without addressing the key underlying causes of modern chronic conditions, that is, lifestyle factors, it is hard to imagine that optimal healthcare can be delivered for all citizens at reduced cost and in a long-term, sustainable fashion [10]. At the Cleveland Clinic, in late 2008 Lifestyle $180^{\circledR}$ was launched with the goal of mitigating the physical and fiscal consequences of preventable chronic diseases. This program employs a system of class-based instruction and ongoing follow-up for participants with common chronic diseases around three key areas: nutrition, physical activity, and stress management. Here, we report findings for participants who completed six months of the program.

\section{Methods}

\section{Participants}

Participants who had at least one of 8 chronic conditions (obesity, hypertension, hyperlipidemia, diabetes, non-alcoholic fatty liver disease, multiple sclerosis, early stage breast or prostate cancer) and had been seen by the primary care physician within three months of enrollment and had provided a note of medical clearance were eligible for participation in the program. Patients who smoked, first enrolled in the Cleveland Clinic's tobacco cessation program before being permitted to enroll in Lifestyle 180 . Patient recruitment was threefold: self-referral, physicianreferral or sponsorship by local self-insured employers. Prior to starting Lifestyle180, participants completed an intake packet that included past medical and surgical histories, pertinent social history, medication use, psychosocial questionnaires and a 1-day food diary.
Considering guidelines from the Third Report of the National Cholesterol Education Program (NCEP) Expert Panel on Detection, Evaluation, and Treatment of High Blood Cholesterol in Adults (Adult Treatment Panel III) [11], the diagnosis of hyperlipidemia was used for participants with:Triglyceride $\geq 150 \mathrm{mg} / \mathrm{dL}$; Total cholesterol $\geq$ $200 \mathrm{mg} / \mathrm{dL}$; LDL cholesterol $\geq 130 \mathrm{mg} / \mathrm{dL}$; HDL cholesterol $<40 \mathrm{mg} / \mathrm{dL}$ for males and $<50 \mathrm{mg} / \mathrm{dL}$ for females, or normal lipids but participant was taking anti-hyperlipidemia medication. The diagnosis of hypertension was used for participants with blood pressure $\geq 140 / 90 \mathrm{mmHg}$ at each of two or more visits taken on separate days or for participants with a normal blood pressure but taking antihypertensive medication. For obesity diagnosis, we used the recommended classifications for BMI adopted by the National Institute of Health and World Health Organization [12]. Overweight $-\mathrm{BMI} \geq 25.0$ to $29.9 \mathrm{~kg} / \mathrm{m}^{2}$; Obesity - BMI $\geq 30 \mathrm{~kg} / \mathrm{m}^{2}$; Obesity Class I - BMI of 30.0 to 34.9 $\mathrm{kg} / \mathrm{m}^{2}$; Obesity Class II - BMI of 35.0 to $39.9 \mathrm{~kg} / \mathrm{m}^{2}$ and Obesity Class III - BMI $\geq 40 \mathrm{~kg} / \mathrm{m}^{2}$. Diagnostic criteria for pre-diabetes and diabetes were from the American Diabetes Association, Diagnosis and Classification of Diabetes Mellitus from January 2011 [13]. Pre-diabetes was indicated by fasting plasma glucose of $100 \mathrm{mg} / \mathrm{dL}$ to $125 \mathrm{mg} /$ $\mathrm{dL}$ or hemoglobin A1c 5.7-6.4\%. For diabetes diagnosis we used fasting plasma glucose of $\geq 126 \mathrm{mg} / \mathrm{dL}$ or hemoglobin A1c $\geq 6.5 \%$. The International Diabetes Federation criteria were used for diagnosis of metabolic syndrome [14]. A person to be defined as having the metabolic syndrome must have central obesity (waist circumference $\geq 94 \mathrm{~cm}$ for men and $\geq 80 \mathrm{~cm}$ for women) plus any two of the following four factors: raised triglyceride level $\geq 150 \mathrm{mg} / \mathrm{dL}$, reduced HDL cholesterol $(<40 \mathrm{mg} / \mathrm{dL}$ in males and $<50$ $\mathrm{mg} / \mathrm{dL}$ in females, raised blood pressure (systolic BP $\geq 130$ $\mathrm{mm} \mathrm{Hg}$ or diastolic $\geq 85 \mathrm{~mm} \mathrm{Hg}$ or raised fasting plasma glucose $\geq 100 \mathrm{mg} / \mathrm{dL}$.

Lifestyle intervention was additive to the treatment plan of all participants who continued medical care from their pre-existing primary care physicians. Participants were instructed to contact their primary physician to adjust medications when deemed necessary, for example when participants' blood pressure and glucose readings started to decrease into subnormal ranges. All hypertensive or diabetic patients were encouraged to monitor daily their blood pressure or fasting glucose, respectively.

An initial $48 \mathrm{hrs}$ of lessons curriculum was taught twice per week, in four-hour sessions each over the first six weeks, called an Immersion Phase. During this period, the first four-hour session of the week was divided into 60 minutes of participant physical activity and 90 minutes of participant cooking and nutrition as well as stress management classes, while during the second session of the week, 60 minutes period was devoted to participant exercise and 
practice of cooking/nutrition, stress management and biometric one-on-one sessions each. The follow-up phase included three components to help maintain behavioral changes. These included 1) on-site classes at weeks 10, 18 and 30 that followed the same four-hour structure as occurred during the Immersion phase on the second day of the week, 2) a weekly e-mail newsletter and 3) the buddy system. Buddies were assigned within each group during the initial six-week session and were asked to keep in daily contact.

\section{Intervention}

Lifestyle 180 was designed by taking into account findings that behaviorally-based lifestyle modification approaches increase the likelihood of sustained changes [15].

Multiple modalities are incorporated into the curriculum, including face-to-face interactions, individuallytailored and group-tailored education sessions and counseling to encourage internal motivation. Participants receive a short syllabus written at 5 th grade level. Three key, closely interconnected, elements of the Lifestyle 180 curriculum included nutrition, physical activity and stress management. Participants enrolled since October 2008 until April 2010 were included in this analysis.

\section{The Nutrition Module}

The primary goal for the nutrition curricular component was to alter patients' diets to foster measurable improvements in biometric and laboratory disease markers. Nutritional aspects of the program most closely align with the Mediterranean diet [16]. The Lifestyle 180 program eliminates trans fats as well as added sugars and syrups, limits saturated fat to $<4 \mathrm{gm} / \mathrm{meal}$ (fish, skinless chicken and skinless turkey breast being the only types of animal food sources) and substitutes only $100 \%$ whole grains/grain products for processed grain foods. Besides complex carbohydrates, Lifestyle 180 nutritional approach promotes an increase in intake of plant foods to provide a spectrum of phytochemicals exerting diverse beneficial biological functions [17]. Improved glycemic control may help reverse or stabilize consequences of diseases such as diabetes and hypertension and possibly beneficially affect aging by activation of the human transcriptional machinery homologue of Caenorhabditis elegans DAF-16 gene complex [18-20]. This food strategy is also likely to promote weight loss, although this is not the primary goal of Lifestyle 180 [21].

The nutritional component of Lifestyle 180 was teamtaught, with a chef and a registered dietitian. First, the chef worked with participants in the teaching kitchen. In an adjoining dining room/classroom, while participants were eating a meal they helped prepare, the dietitian conducted a seminar and guided a discussion about the nutritional aspects of what they had cooked as well as a covered topic of the day. To motivate participants to change how and what they eat, they were engaged into meal preparation in the kitchen. Gaining confidence with the kitchen equipment and different types of foods as well as learning how to manage time during meal preparation were considered important elements of the efforts to increase the likelihood that participants will change their dietary habits. As part of the nutrition education of participants, one class during the Immersion Phase involved a grocery store experience. In this environment, participants learned how to read nutrition and ingredient labels, what to avoid in packaged foods and how to "shop" a grocery store (i.e. what aisles to avoid, which to frequent).

\section{The Physical Activity Module}

The goal of the physical activity component of Lifestyle 180 was to increase both endurance and strength of participants. Current guidelines for adults recommend at least 150 minutes of physical activity per week to maintain fitness levels and at least 200 minutes per week for waist circumference reduction and weight loss [22]. An exercise instructor led the class in the Lifestyle 180 Fitness Center that included progressive cardiovascular and endurance training as well as resistance training. Patients chose between treadmills, elliptical machines, stationary bicycles or Concept Rowers. Resistance equipment includes dumbbells (2-15 lb each), stretch bands (resistance tubing: extra light, light, medium and heavy) and medicine balls (2-15 lbs each). The goal was to teach participants how to engage in physical activities in a safe and effective manner and to enable them to gain the skills to exercise and progress on their own, including resistance exercise. They were taught that increased resistance type activity helps lose and maintain weight loss. In particular, visceral adipose tissue is preferentially lost, while maintaining muscle mass [23,24]. Patients were encouraged to wear pedometers that were provided at start of the Program, with a goal of 10,000 steps per day and to record their steps on a daily diary sheet $[25,26]$. These data were used to monitor participants' progress in exercise.

\section{The Stress Management Module}

This component was team-taught, with a restorative yoga therapist and a behavioral health specialist. To sustain healthy lifestyle modifications, behavioral interventions were implemented during the course of the program. Those included goal setting, keeping records of lifestyle practices, social support, cognitive restructuring and problem solving. Patients learned meditation and mindfulness practices and performed simple yoga poses initially sitting or standing and at later stages of the program lying down. Regular elicitation of the "relaxation response", the physiological opposite of the "fight or 
flight response", may reduce psychological distress and improve medical symptoms in patients with any of a wide array of medical conditions [27]. These practices were integrated into the program to teach participants how to be present in the moment, more aware of their thoughts and feelings to recognize old thoughts and patterns that no longer serve them and release those unhelpful ways of thinking and believing. The focus was on accountability and compliance with the program and for that purpose a daily diary checklist was reviewed in each class by the behavioral health specialist and weekly by the physician and nurse case manager during one-on-one sessions with each participant.

\section{Outcome Assessment}

To measure the effectiveness of the Program, we established an IRB-approved patient registry (Cleveland Clinic Foundation IRB number 09-154) to collect biometric, metabolic and psychosocial data. At each one-on-one session, body weight, waist circumference, resting heart rate and blood pressure were recorded while height was measured only at the start of the program for body mass index (BMI, calculated as weight in kilograms divided by height in meters squared) calculation. Participants were in socks and lightly dressed when body weight and height were measured. Waist circumference was measured by a tape measure in the midspace between the lowest costal margin and the iliac crest. Blood pressure was measured by the standard manual protocol using sphygmomanometer. In addition, patients were queried weekly regarding their medications and changes in medications were recorded. Patients and their physicians were given the results of the biometrics and metabolic variables as they were obtained. At the beginning of the program, participants completed a 1-day food diary that was analyzed by a registered dietitian and reviewed with the participant during week one of the Immersion phase.

Laboratory measures included total cholesterol (to convert from $\mathrm{mg} / \mathrm{dL}$ to millimoles per liter, divided by 38.67 ), triglycerides (to convert from $\mathrm{mg} / \mathrm{dL}$ to millimoles per liter, divided by 88.57), low-density lipoprotein cholesterol (LDL-C), high-density lipoprotein cholesterol (HDL-C) by standard enzymatic methodology, hemoglobin A1c (HgbA1c) (in percentages \%) by turbidimetric inhibition immunoassay, insulin (to convert from microIU/ml to picomoles per liter divided by 6.94) by chemiluminescence immunoassay, ultra sensitive C-reactive protein (US-CRP) (to convert from $\mathrm{mg} / \mathrm{L}$ to nanomoles per liter divide by 8.45 ) by immunoturbidometric assay and fasting plasma glucose (to convert from $\mathrm{mg} / \mathrm{dL}$ to millimoles per liter divided by 18) by glucose hexokinase method. These values were measured at the beginning of the study (week 1 ) and at weeks 6 and 30. Hemoglobin A1c was not evaluated at week 6 .

\section{Statistical Methods}

Continuous variables were presented as mean \pm SD and categorical variables as n (\%). For univariable analyses, changes in outcomes at 6 and 30 weeks from baseline were assessed with the paired t-test. Analysis of covariance was used to assess the relationship between weight loss and baseline variables obesity status, diabetic status, hyperlipidemia, hypertension, metabolic syndrome while adjusting for age, gender and payment options. We also report the percentage of participants who experience weight loss of $2.3 \mathrm{~kg}$ or more, that is, beyond the change expected with normal daily weight fluctuation [28]. Results estimate changes from baseline and not efficacy of the wellness program. Patients with incomplete data at either baseline or follow-up were excluded when assessing change or percent change from baseline, as were patients with missing covariables for multivariable models. No imputation of data of missing data values was done. All reported P values are two-sided and the significance level was 0.05 for each hypothesis; a Bonferroni adjustment for multiple comparisons over time within each hypothesis was made (i.e., significance criterion at each of 6 and 30 weeks was $0.05 / 2=$ 0.025). SAS statistical software, Carey, NC, was used for all analyses.

\section{Results}

\section{Characteristics of participants}

Baseline characteristics of participants are shown in Table 1. The mean age of 429 participants was 52 years, more participants were female (65\%), 32\% of participants had diabetes, $59 \%$ had hyperlipidemia, $63 \%$ had hypertension, $80 \%$ were obese and $59 \%$ fulfilled the diagnostic criteria for metabolic syndrome and $40 \%$ for pre-diabetes $[13,14]$. The number of participants with other chronic conditions, including breast and prostate cancer, fatty liver and multiple sclerosis was much smaller (less than $5 \%)$.

At week 6 (the end of the Immersion Phase) 404/429 (94\%) of participants had biometric measurements taken and 396/429 (92\%) had labs drawn, while at week 30, $244 / 429$ (57\%) returned on time for a follow up and 299/429 (70\%) had labs drawn.

There were few, but important differences in mean baseline variables between these participants who had either biometric or metabolic data available at their week 30 visit and those who did not, six week variables, or change from baseline to six weeks. Specifically, those who had week 30 biometrics completed were less likely to have obesity and greater lowering of mean cholesterol and LDL at six weeks than those who did not have week 30 data. Those who had week 30 cholesterol data (as an indicator of blood work being completed) were more likely to have greater lowering in mean weight, triglycerides, cholesterol and LDL than those with cholesterol levels not available (Table 2). 
Table 1 Basic Characteristics of Patients $(N=429)^{a}$

\begin{tabular}{|c|c|}
\hline Variable & Statistics $^{\mathbf{b}}$ \\
\hline Female N (\%) & $278(65)$ \\
\hline Obese (BMI > 30) N (\%) & $345(80)$ \\
\hline Pre-diabetes N (\%) & $170(40)$ \\
\hline Diabetes N (\%) & $139(32)$ \\
\hline Hyperlipidemia N (\%) & $255(59)$ \\
\hline Hypertension N (\%) & $270(63)$ \\
\hline Metabolic syndrome $\mathrm{N}(\%)^{c}$ & $247(59)$ \\
\hline Age (years) & $52 \pm 11$ \\
\hline Height $(\mathrm{cm})$ & $168 \pm 9$ \\
\hline Weight (kg) & $103 \pm 25$ \\
\hline $\mathrm{BMI}\left(\mathrm{kg} / \mathrm{m}^{2}\right)$ & $37 \pm 8$ \\
\hline Waist $(\mathrm{cm})^{\mathrm{d}}$ & $114 \pm 18$ \\
\hline $\mathrm{SBP}(\mathrm{mmHg})$ & $132 \pm 15$ \\
\hline $\mathrm{DBP}(\mathrm{mmHg})$ & $82 \pm 10$ \\
\hline Heart rate (bpm) & $78 \pm 11$ \\
\hline Fasting Glucose $(\mathrm{mg} / \mathrm{dL})^{\mathrm{e}}$ & $108 \pm 35(6.0 \pm 1.9 \mathrm{mmol} / \mathrm{L})$ \\
\hline Triglycerides $(\mathrm{mg} / \mathrm{dL})^{f}$ & $137 \pm 81(1.5 \pm 0.9 \mathrm{mmol} / \mathrm{L})$ \\
\hline Cholesterol $(\mathrm{mg} / \mathrm{dL})^{\mathrm{f}}$ & $187 \pm 39(4.8 \pm 1.0 \mathrm{mmol} / \mathrm{L})$ \\
\hline $\mathrm{HDL}(\mathrm{mg} / \mathrm{dL})^{\mathrm{f}}$ & $51 \pm 15(1.3 \pm 0.4 \mathrm{mmol} / \mathrm{L})$ \\
\hline $\operatorname{LDL}(\mathrm{mg} / \mathrm{dL})^{\mathrm{e}}$ & $109 \pm 33(2.8 \pm 0.9 \mathrm{mmol} / \mathrm{L})$ \\
\hline $\operatorname{HgbA1c}(\%)^{j}$ & $6 \pm 1$ \\
\hline Insulin (microU/mL) & $19 \pm 18(131 \pm 122 \rho \mathrm{pmol})$ \\
\hline US-CRP (mg/dL) & $5 \pm 8(45 \pm 66 \mathrm{nmol} / \mathrm{L})$ \\
\hline
\end{tabular}

Abbreviations: BMI, body mass index; SBP, systolic blood pressure; DBP, diastolic blood pressure; HDL, high-density lipoprotein cholesterol; LDL, lowdensity lipoprotein cholesterol; HgbA1c, hemoglobin A1c; US-CRP, ultra sensitive c-reactive protein.

${ }^{a}$ Insulin ( $\left.=271\right)$ and US-CRP $(\mathrm{N}=285)$ only measured beginning June 2009.

${ }^{b} \mathrm{~N}(\%)$ or mean \pm SD.

c, $d, e, f, j$ indicate $7,1,9,6$ and 34 missing data points, respectively.

\section{Biometric changes}

Table 3 presents descriptive statistics between baseline, 6 and 30 weeks (Figure 1). Mean weight change over 30 weeks was $6.8 \pm 6.9 \mathrm{~kg}$ (Table 4). Of 244 participants who were measured at both baseline and 30 weeks, 183 (75\%) had $2.3 \mathrm{~kg}$ or more weight loss, 66 (27\%) had over a $5 \%$ weight loss and 67 additional (28\%) had over a $10 \%$ weight loss; 24 (10\%) of participants gained weight. The mean body mass index at 30 weeks was $33 \pm 8 \mathrm{~kg} / \mathrm{m}^{2}$, and mean waist circumference was $105 \pm 16 \mathrm{~cm}$. The mean \pm SD systolic blood pressure at 30 weeks was $129 \pm 14 \mathrm{mmHg}$. All biometric changes at 6 and 30 weeks were significantly decreased from baseline (paired t-test, all $\mathrm{P}<0.001$, except systolic blood pressure $(\mathrm{P}=0.022)$ ) (Table 4$)$.

\section{Metabolic changes}

Results for metabolic measures are presented in Table 5 at each point in time, while changes from baseline are shown in Table 6 and Figure 2. Means of all metabolic measures were significantly lower at 6 weeks compared with baseline (all $\mathrm{P}<0.025$ ). Mean glucose, total cholesterol, triglycerides, LDL, HgbA1c, insulin and US-CRP were also significantly lower at 30 weeks compared with baseline, while mean HDL levels rose $3.7 \pm 8.4 \mathrm{mg} / \mathrm{dL}$ $(0.10 \pm 0.22 \mathrm{mmol} / \mathrm{L})(\mathrm{P}<0.001)$. In general, changes at 30 weeks were sustained, but sometimes less than at 6 weeks.

\section{Change in metabolic syndrome status}

By International Diabetes Federation criteria [14], 247 (59\%) out of 422 participants were identified as having metabolic syndrome at baseline. Of the 382 participants for whom metabolic syndrome status (yes or no) could be determined at both baseline and 6 weeks, the percent with metabolic syndrome dropped from 58\% (223/382) at baseline to $44 \%(167 / 382)$ at 6 weeks (McNemar's test, $\mathrm{P}<0.001)$. Similarly, the percent with metabolic syndrome dropped from $54 \%(138 / 257)$ at baseline to $37 \%(94 / 257)$ at 30 weeks $(\mathrm{P}<0.001)$.

\section{Relationship between clinical conditions and weight loss}

Table 7 shows the relationship between clinical conditions and weight loss at 6 and 30 weeks from baseline. Mean weight loss was higher in the obese than in non-obese participants at both 6 weeks $(4.2 \pm 2.7$ vs. $2.3 \pm 1.9 \mathrm{~kg}$, multivariable $\mathrm{P}<0.001)$ and 30 weeks $(7.6 \pm 7.4$ vs. $4.2 \pm 4.1$ $\mathrm{kg}$, multivariable $\mathrm{P}<0.001)$. However, there was no difference in mean percent weight loss between the obese and non-obese participants at either 6 weeks (multivariable $\mathrm{P}=0.033$ ) or 30 weeks (multivariable $\mathrm{P}=0.038$ ). The factors diabetic, hyperlipidemia, hypertension, and metabolic syndrome were not associated with the weight loss at 6 and 30 weeks (All P > 0.025).

\section{Change in medication use}

The summary of self-reported changes in medications for diabetes, hyperlipidemia and hypertension at week 30 is shown in Table 8. Participants' primary physicians adjusted medications (not the Lifestyle 180 medical team) as deemed necessary. Medication changes included beneficial categories of a) stopped medication (151 medications), b) decreased dose of medication (89 medications) or c) avoided medication (24 medications). Participants in the "avoided" category had, for example, abnormally elevated LDL cholesterol or hemoglobin A1c or were diagnosed with hypertension at baseline and were advised by their primary care physicians to start taking medications, but they refused. At week 30 their blood tests, or blood pressure were within normal ranges and they thus avoided the need to use a particular medication. On the opposite side, there were participants whose baseline or week 6 laboratory findings and blood pressure values were consistently abnormal or did not improve thus requiring that they start taking new medications (a total of 62 medications, 36 of those for uncontrolled hypertension) or increase the dose of their current 
Table 2 Association between compliance at 30 weeks and baseline conditions ${ }^{a}$

\begin{tabular}{|c|c|c|c|c|c|c|}
\hline \multirow[t]{2}{*}{ Variable } & \multicolumn{2}{|c|}{ 30-week Weight available } & \multirow{2}{*}{$\begin{array}{c}P \\
\text { value }\end{array}$} & \multicolumn{2}{|c|}{ 30-week Cholesterol available } & \multirow[t]{2}{*}{$P$ value } \\
\hline & Yes $(N=243)$ & No $N=(186)$ & & $\begin{array}{c}\text { Yes } \\
(\mathrm{N}=295)\end{array}$ & $\begin{array}{c}\text { No } \\
(\mathrm{N}=128)\end{array}$ & \\
\hline \multicolumn{7}{|l|}{ Baseline conditions: } \\
\hline Diabetes N (\%) & $176(72)$ & $133(72)$ & 0.97 & $220(75)$ & $88(69)$ & 0.26 \\
\hline $\begin{array}{l}\text { Obesity (BMl> 30) N (\%) } \\
\text { N (\%) }\end{array}$ & $185(76)$ & $160(95)$ & $0.011^{b}$ & $232(79)$ & $108(84)$ & 0.17 \\
\hline Hyperlipidemia N (\%) & $151(62)$ & $104(56)$ & 0.19 & $185(63)$ & $68(53)$ & 0.065 \\
\hline Hypertension N (\%) & $155(64)$ & $115(62)$ & 0.68 & $193(65)$ & $73(57)$ & 0.10 \\
\hline Metabolic syndrome N (\%) & $135(56)$ & $112(61)$ & 0.33 & $175(60)$ & $71(56)$ & 0.47 \\
\hline \multicolumn{7}{|l|}{ Biometrics at week 6: } \\
\hline Weight (kg) & $95 \pm 22$ & $105 \pm 26$ & $<0.001^{\mathrm{b}}$ & $96 \pm 22$ & $105 \pm 26$ & $0.002^{b}$ \\
\hline Waist (cm) & $107 \pm 15$ & $112 \pm 17$ & $0.002^{b}$ & $108 \pm 15$ & $112 \pm 18$ & $0.046^{\mathrm{b}}$ \\
\hline Body mass index $\left(\mathrm{kg} / \mathrm{m}^{2}\right)$ & $34 \pm 7$ & $37 \pm 8$ & $<0.001^{\mathrm{b}}$ & $34 \pm 7$ & $37 \pm 8$ & $0.004^{b}$ \\
\hline Systolic blood pressure $(\mathrm{mmHg})$ & $126 \pm 13$ & $127 \pm 15$ & 0.66 & $126 \pm 13$ & $127 \pm 15$ & 0.69 \\
\hline Diastolic blood pressure (mmHg) & $79 \pm 8$ & $79 \pm 9$ & 0.78 & $79 \pm 8$ & $79 \pm 9$ & 0.90 \\
\hline Heart rate (bpm) & $71 \pm 11$ & $73 \pm 12$ & 0.056 & $71 \pm 11$ & $74 \pm 12$ & $0.014^{b}$ \\
\hline \multicolumn{7}{|l|}{ Metabolic variables at week 6: } \\
\hline Glucose (mg/dL) & $101 \pm 25$ & $104 \pm 27$ & 0.32 & $101 \pm 24$ & $104 \pm 30$ & 0.40 \\
\hline$(\mathrm{mmol} / \mathrm{L})$ & $5.6 \pm 1.4$ & $5.8 \pm 1.5$ & & $5.6 \pm 1.3$ & $5.8 \pm 1.7$ & \\
\hline Triglycerides (mg/dL) & $102 \pm 49$ & $115 \pm 54$ & $0.02^{b}$ & $103 \pm 49$ & $118 \pm 57$ & $0.023^{b}$ \\
\hline$(\mathrm{mmol} / \mathrm{L})$ & $1.2 \pm 0.6$ & $1.3 \pm 0.6$ & & $1.2 \pm 0.6$ & $1.3 \pm 0.6$ & \\
\hline Cholesterol (mg/dL) & $164 \pm 35$ & $170 \pm 38$ & 0.11 & $164 \pm 36$ & $171 \pm 37$ & 0.08 \\
\hline$(\mathrm{mmol} / \mathrm{L})$ & $4.2 \pm 0.9$ & $4.4 \pm 1.0$ & & $4.2 \pm 0.9$ & $4.4 \pm 1.0$ & \\
\hline High-density lipoprotein (mg/dL) & $51 \pm 15$ & $48 \pm 13$ & 0.08 & $50 \pm 14$ & $49 \pm 15$ & 0.33 \\
\hline Cholesterol (mmol/L) & $1.3 \pm 0.4$ & $1.2 \pm 0.3$ & & $1.3 \pm 0.4$ & $1.3 \pm 0.4$ & \\
\hline Low-density lipoprotein (mg/dL) & $92 \pm 29$ & $99 \pm 34$ & 0.06 & $93 \pm 30$ & $99 \pm 33$ & 0.11 \\
\hline Cholesterol (mmol/L) & $2.4 \pm 0.7$ & $2.6 \pm 0.9$ & & $2.4 \pm 0.8$ & $2.6 \pm 0.9$ & \\
\hline \multicolumn{7}{|c|}{ Change in biometrics from baseline to six weeks: } \\
\hline Weight (kg) & $-4.0 \pm 2.5$ & $-3.6 \pm 2.8$ & 0.16 & $-4.1 \pm 2.6$ & $-3.1 \pm 2.7$ & $<0.001^{b}$ \\
\hline Waist (cm) & $-4.0 \pm 4.1$ & $-4.4 \pm 4.2$ & 0.36 & $-4.2 \pm 4.1$ & $-4.0 \pm 4.4$ & 0.66 \\
\hline Body mass index $\left(\mathrm{kg} / \mathrm{m}^{2}\right)$ & $-1.4 \pm 0.9$ & $-1.3 \pm 1.0$ & 0.12 & $-1.5 \pm 0.9$ & $-1.1 \pm 0.9$ & $<0.001^{\mathrm{b}}$ \\
\hline Systolic blood pressure (mmHg) & $-5.1 \pm 15.7$ & $-5.1 \pm 15.2$ & 0.98 & $-5.8 \pm 15.1$ & $-3.7 \pm 16.6$ & 0.24 \\
\hline Diastolic blood pressure $(\mathrm{mmHg})$ & $-2.7 \pm 8.6$ & $-3.9 \pm 10.9$ & 0.24 & $-3.1 \pm 9.2$ & $-3.5 \pm 10.7$ & 0.75 \\
\hline Heart rate (bpm) & $-4.7 \pm 1.7$ & $-6.2 \pm 11.2$ & 0.20 & $-5.4 \pm 10.9$ & $-5.3 \pm 12.8$ & 0.92 \\
\hline \multicolumn{7}{|c|}{ Change in metabolic variables from baseline to six weeks: } \\
\hline Glucose (mg/dL) & $-6 \pm 24$ & $-6 \pm 25$ & 0.96 & $-6 \pm 22$ & $-7 \pm 29$ & 0.67 \\
\hline$(\mathrm{mmol} / \mathrm{L})$ & $-0.3 \pm 1.3$ & $-0.3 \pm 1.4$ & & $-0.3 \pm 1.2$ & $-0.4 \pm 1.6$ & \\
\hline Triglycerides (mg/dL) & $-31 \pm 55$ & $-23 \pm 51$ & 0.12 & $-32 \pm 55$ & $-17 \pm 49$ & $0.010^{\mathrm{b}}$ \\
\hline$(\mathrm{mmol} / \mathrm{L})$ & $-0.4 \pm 0.6$ & $-0.3 \pm 0.6$ & & $-0.4 \pm 0.6$ & $-0.2 \pm 0.6$ & \\
\hline Cholesterol (mg/dL) & $-25 \pm 26$ & $-17 \pm 25$ & $<0.001^{\mathrm{b}}$ & $-24 \pm 28$ & $-14 \pm 19$ & $<0.001^{b}$ \\
\hline$(\mathrm{mmol} / \mathrm{L})$ & $-0.7 \pm 0.7$ & $-0.4 \pm 0.6$ & & $-0.6 \pm 0.7$ & $-0.4 \pm 0.5$ & \\
\hline High-density lipoprotein (mg/dL) & $-2.3 \pm 7$ & $-1.7 \pm 6$ & 0.37 & $-1.9 \pm 7.0$ & $-2.4 \pm 6.0$ & 0.50 \\
\hline Cholesterol (mmol/L) & $-0.1 \pm 0.2$ & $-0.0 \pm 0.2$ & & $-0.0 \pm 0.2$ & $-0.1 \pm 0.2$ & \\
\hline Low-density lipoprotein (mg/dL) & $-17 \pm 21$ & $-10 \pm 21$ & $<0.001^{\mathrm{b}}$ & $-17 \pm 22$ & $-8 \pm 19$ & $<0.001^{b}$ \\
\hline Cholesterol (mmol/L) & $-0.5 \pm 0.6$ & $-0.3 \pm 0.5$ & & $-0.4 \pm 0.6$ & $-0.2 \pm 0.5$ & \\
\hline
\end{tabular}

${ }^{a}$ Statistics represent $\mathrm{N}(\%)$ and mean $\pm \mathrm{SD}$. $P$ values from the chi-square test or t-test, as appropriate.

${ }^{\mathrm{b}}$ Significant if $P<0.05$ (no correction testing at multiple weeks, to be conservative). 
Table 3 Biometric outcomes: descriptive statistics by week of follow-up

\begin{tabular}{lcccccc}
\hline Factor & \multicolumn{2}{c}{$\begin{array}{c}\text { Week One } \\
\text { (N = 429) }\end{array}$} & \multicolumn{2}{c}{$\begin{array}{c}\text { Week Six } \\
(\mathbf{N}=\mathbf{4 0 4})\end{array}$} & $\begin{array}{c}\text { Week 30 } \\
\text { (N = 244) }\end{array}$ \\
\cline { 2 - 7 } & Mean \pm SD & Min-Max & Mean \pm SD & Min-Max & Mean \pm SD & Min-Max \\
\hline Weight (kg) & $103 \pm 25$ & $49-205$ & $99 \pm 24$ & $46-200$ & $92 \pm 22^{\mathrm{a}}$ & $46-216$ \\
Waist (cm) & $114 \pm 18^{\mathrm{a}}$ & $66-167$ & $109 \pm 16^{\mathrm{b}}$ & $66-163$ & $105 \pm 16^{\mathrm{c}}$ & $66-186$ \\
SBP (mmHg) & $132 \pm 15$ & $92-188$ & $127 \pm 14$ & $94-181$ & $129 \pm 14^{\mathrm{b}}$ & $100-180$ \\
DBP(mmHg) & $82 \pm 10$ & $50-120$ & $79 \pm 8$ & $48-112$ & $79 \pm 8^{\mathrm{b}}$ & $58-98$ \\
HR (bpm) & $78 \pm 11$ & $52-114$ & $72 \pm 12^{\mathrm{a}}$ & $43-115$ & $71 \pm 10$ & $40-108$ \\
BMI (kg/m $\left.{ }^{2}\right)$ & $37 \pm 8$ & $19-70$ & $35 \pm 8$ & $19-69$ & $33 \pm 8^{\mathrm{a}}$ & $18-74$ \\
\hline
\end{tabular}

Abbreviations: BMI, body mass index.

a, b, c indicate 1, 2, and 6 missing data points, respectively.

medication(s) (18 medications). A total of 35 medication changes were made in the same category (for example, a diuretic was replaced with a calcium channel blocker) (data not shown). As shown in Table 8, for every newly started medication or one with increased dose, 3.3 medications were stopped, reduced in dose or avoided. This ratio was even better (4.0) in case of diabetes and hyperlipidemia medications.

\section{Discussion}

Preventable chronic diseases continue to drive health care costs substantially and importantly upward, in part due to a lack of sustainable treatment options. Specific medications, such as cholesterol-lowering and diabetes medications target mostly one chronic disease-associated abnormality of elevated LDL cholesterol or plasma

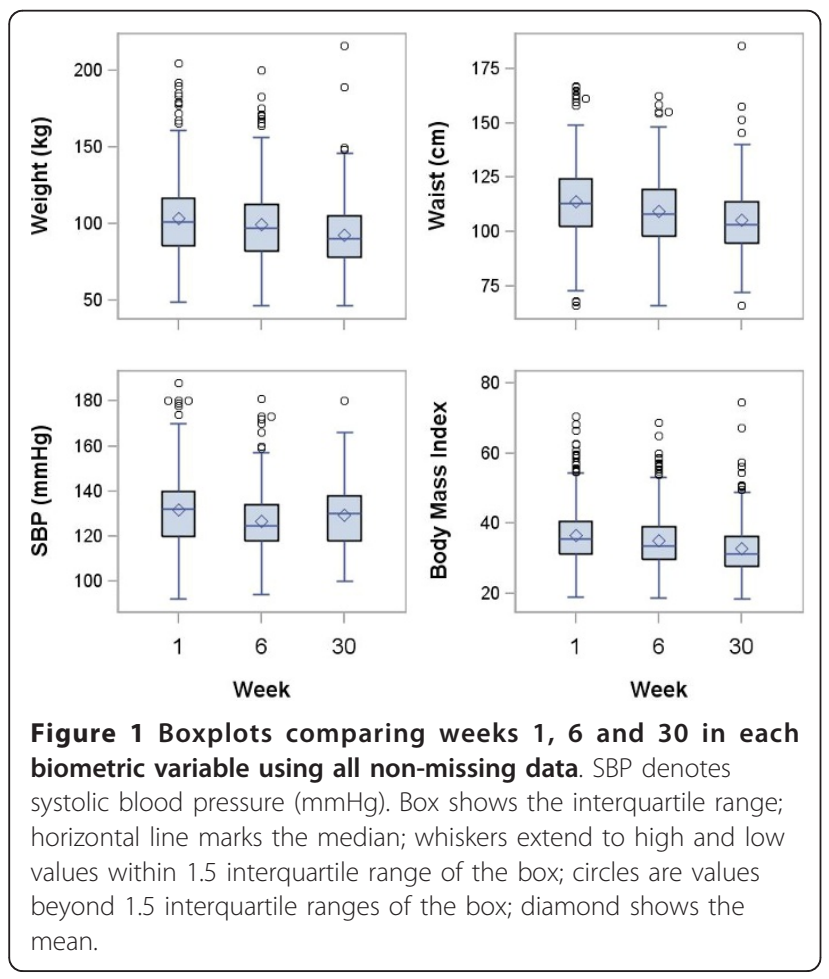

glucose, respectively, rather than the cause of the abnormality. While surgical interventions successfully treat obesity and a spectrum of associated metabolic changes, they poorly address the behavioral and lifestylerelated factors that led to the development of chronic conditions in the first place. In contrast, comprehensive lifestyle interventions may result in multiple physiological systems changes including behavior modifications that support long-term healthier lifestyle choices [5,29].

Here, we report findings that a tri-pronged lifestyle intervention consisting of diet, physical activity and stress management improves disease-associated markers of participants with multiple chronic conditions. All measured biometric and laboratory variables significantly improved after just 6 weeks of intervention. Beneficial changes in blood pressure and glucose were observed in many participants by the second week of the program, thus supporting previously reported observations of the quick onset of measurable benefits that follow a comprehensive lifestyle intervention [8]. Serum HDL cholesterol decrease after 6 weeks was most likely associated with early weight loss, as reported [30]. Nevertheless, reductions in total cholesterol are more profound than in HDL cholesterol, resulting in improved ratio of total cholesterol to HDL cholesterol, an

Table 4 Biometric outcomes: changes from baseline to six and thirty weeks

\begin{tabular}{|c|c|c|c|c|}
\hline \multirow[t]{2}{*}{ Factor } & \multicolumn{2}{|c|}{$\begin{array}{c}\text { Week } 6 \text { change from } \\
\text { baseline } \\
(N=404)\end{array}$} & \multicolumn{2}{|c|}{$\begin{array}{c}\text { Week } 30 \text { change from } \\
\text { baseline } \\
(\mathrm{N}=244)\end{array}$} \\
\hline & Mean \pm SD & $P$ value $^{\mathrm{a}}$ & Mean \pm SD & $P$ value ${ }^{\mathrm{a}}$ \\
\hline Weight (kg) & $-3.8 \pm 2.6$ & $<0.001$ & $-6.8 \pm 6.9^{c}$ & $<0.001$ \\
\hline Waist (cm) & $-4.2 \pm 4.2^{b}$ & $<0.001$ & $-6.1 \pm 7.3^{d}$ & $<0.001$ \\
\hline $\mathrm{SBP}(\mathrm{mmHg})$ & $-5.1 \pm 15.5$ & $<0.001$ & $-2.5 \pm 17.1^{e}$ & 0.022 \\
\hline $\mathrm{DBP}(\mathrm{mmHg})$ & $-3.2 \pm 9.6$ & $<0.001$ & $-2.5 \pm 10.0^{\mathrm{e}}$ & $<0.001$ \\
\hline $\mathrm{HR}$ (bpm) & $-5.3 \pm 11.5^{c}$ & $<0.001$ & $-5.3 \pm 11.5$ & $<0.001$ \\
\hline BMI $\left(\mathrm{kg} / \mathrm{m}^{2}\right)$ & $-1.3 \pm 0.9$ & $<0.001$ & $-2.4 \pm 2.4^{c}$ & $<0.001$ \\
\hline
\end{tabular}

Abbreviations: BMI, body mass index; SBP, systolic blood pressure; DBP,

diastolic blood pressure; HR, heart rate.

${ }^{a} P$ value from paired t-test, significant if $P<0.025$.

$\mathrm{b}, \mathrm{c}, \mathrm{d}, \mathrm{e}$ indicate $3,1,6$ and 2 missing data points, respectively. 
Table 5 Metabolic outcomes by week

\begin{tabular}{|c|c|c|c|c|c|c|c|}
\hline \multirow[t]{2}{*}{ Factor } & \multirow[t]{2}{*}{ Units } & \multicolumn{2}{|c|}{$\begin{array}{l}\text { Week One } \\
(\mathrm{N}=423)\end{array}$} & \multicolumn{2}{|c|}{$\begin{array}{l}\text { Week Six } \\
(\mathrm{N}=396)\end{array}$} & \multicolumn{2}{|c|}{$\begin{array}{c}\text { Week } 30 \\
(\mathrm{~N}=299)\end{array}$} \\
\hline & & Mean \pm SD & Min - Max & Mean \pm SD & Min - Max & Mean \pm SD & Min -Max \\
\hline \multirow[t]{2}{*}{ Glucose } & $(\mathrm{mg} / \mathrm{dL})$ & $108 \pm 35^{b}$ & $67-330$ & $102 \pm 27^{c}$ & $62-264$ & $103 \pm 29$ & $59-339$ \\
\hline & $(\mathrm{mmol} / \mathrm{L})$ & $6.0 \pm 1.9$ & $3.7-18.3$ & $5.7 \pm 1.5$ & $3.4-14.7$ & $5.7 \pm 1.6$ & $3.3-18.8$ \\
\hline \multirow[t]{2}{*}{ Triglycerides } & $(\mathrm{mg} / \mathrm{dL})$ & $137 \pm 81$ & $34-839$ & $107 \pm 51$ & $34-405$ & $109 \pm 52^{d}$ & $32-331$ \\
\hline & $(\mathrm{mmol} / \mathrm{L})$ & $1.5 \pm 0.9$ & $0.4-9.5$ & $1.2 \pm 0.6$ & $0.4-4.6$ & $1.2 \pm 0.6$ & $0.4-3.7$ \\
\hline \multirow[t]{2}{*}{ Cholesterol } & $(\mathrm{mg} / \mathrm{dL})$ & $187 \pm 39$ & $82-307$ & $166 \pm 36$ & $80-294$ & $179 \pm 38^{d}$ & $93-290$ \\
\hline & $(\mathrm{mmol} / \mathrm{L})$ & $4.8 \pm 1.0$ & $2.1-7.9$ & $4.3 \pm 0.9$ & $2.1-7.6$ & $4.6 \pm 1.0$ & $2.4-7.5$ \\
\hline \multirow[t]{2}{*}{$\overline{\mathrm{HDL}}$} & $(\mathrm{mg} / \mathrm{dL})$ & $51 \pm 15$ & $24-128$ & $50 \pm 14$ & $21-110$ & $55 \pm 16^{d}$ & $21-147$ \\
\hline & $(\mathrm{mmol} / \mathrm{L})$ & $1.3 \pm 0.4$ & $0.6-3.3$ & $1.3 \pm 0.4$ & $0.5-2.8$ & $1.4 \pm 0.4$ & $0.5-3.8$ \\
\hline \multirow[t]{2}{*}{$\overline{\mathrm{LDL}}$} & $(\mathrm{mg} / \mathrm{dL})$ & $109 \pm 33^{b}$ & $21-218$ & $95 \pm 31$ & $17-225$ & $102 \pm 32^{e}$ & $26-215$ \\
\hline & $(\mathrm{mmol} / \mathrm{L})$ & $2.8 \pm 0.9$ & $0.5-5.6$ & $2.5 \pm 0.8$ & $0.4-5.8$ & $2.6 \pm 0.8$ & $0.7-5.6$ \\
\hline HgbA1c & $(\%)$ & $6 \pm 1^{c}$ & $5-13$ & N/A & $\mathrm{N} / \mathrm{A}$ & $6 \pm 1^{f}$ & $5-10$ \\
\hline \multirow[t]{2}{*}{ Insulin } & (microU/dL) & $19 \pm 18$ & $3-134$ & $14 \pm 14$ & $1-126$ & $13 \pm 10$ & $0.5-72$ \\
\hline & (pmol/L) & $131 \pm 122$ & $17-930$ & $97 \pm 97$ & $7-877$ & $87 \pm 73$ & $3.5-500$ \\
\hline \multirow[t]{2}{*}{$\overline{U S-C R P}$} & $(\mathrm{mg} / \mathrm{mL})$ & $5 \pm 8$ & $0.1-88$ & $4 \pm 5$ & $0.2-33$ & $4 \pm 6$ & $0.2-39$ \\
\hline & $(\mathrm{nmol} / \mathrm{L})$ & $45 \pm 66$ & $0.8-740$ & $33 \pm 45$ & $1.7-278$ & $33 \pm 48$ & $1.7-331$ \\
\hline
\end{tabular}

Abbreviations: HDL, high-density lipoprotein cholesterol; LDL, low-density lipoprotein cholesterol; HgbA1c, hemoglobin A1c; US-CRP, ultra sensitive c-reactive protein. N/A, no required measurement at six weeks.

${ }^{a} \mathrm{~N}=271,266$ and 185 for insulin and $\mathrm{N}=285,273$ and 201 for US-CRP at weeks 1, 6, and 30, respectively, since neither parameter measured before June 2009; b, c, d, e, f indicate 3, 28, 7, 2, 1 and 15 missing data points, respectively.

established risk factor for coronary artery disease [31]. Although HDL cholesterol generally decreases during weight loss, it increases following weight maintenance in proportion to the amount of weight that is lost $[32,33]$. At week 30 , HDL cholesterol is significantly higher than at the baseline and the total cholesterol/HDL ratio improves further. Fasting triglyceride level is also significantly reduced at both points in time (week 6 and 30) compared with baseline, reflecting the observations that triglycerides improve after weight loss [34]. Fasting hypertriglyceridemia is an established risk factor for cardiovascular disease and may predict disease progression [35]. In addition, TG/ HDL ratio, a possible powerful predictor of extensive coronary artery disease is also improved, that is, decreased significantly [36]. In our study, we did not examine if these beneficial changes lead to better cardiovascular outcomes. In a comprehensive lifestyle intervention similar to ours, where a low-fat plant-based diet rather then a Mediterranean-style diet was used, reductions in total and LDL cholesterol were of greater magnitude than in this study and were associated with the arrest and/or reversal of coronary artery disease [5,37].

A large proportion of the global burden of chronic diseases, particularly cardiovascular disease, obesity and some cancers, involves non-resolving, chronic inflammation [38]. Lifestyle 180 intervention resulted in significantly healthier markers of glucose metabolism and inflammation (Table 6). Although measurements of insulin and US-CRP were initiated at later stages of the program and data were available for smaller number of participants, these results show large percentage decreases, strengthening the evidence that these lifestyle interventions may be used as anti-inflammatory therapies to treat insulin resistance, beneficially impact metabolic syndrome and associated chronic diseases [39]. It is, therefore, not surprising that the percent of participants with metabolic syndrome was significantly lower after 6 months of lifestyle interventions (an estimated relative 32 percent lower, from $54 \%$ to $37 \%$ ).

Here we report only the outcomes for those participants who had biometric and lab measurements. These participants had greater lowering of mean weight and cholesterol at week 6 than those who did not attend this follow up. Thus, it is likely that those who witnessed greater early successes in their outcomes were more motivated to remain engaged in the program. We were unable to obtain biometric and laboratory measurements of patients who dropped out at 6 months, but the observed differences at 6 weeks suggest that those patients who dropped out at 6 months may have done so because their outcomes were not as good as for those who remained. At six months, $30-43 \%$ attrition rate (laboratory data and biometrics, respectively) was comparable to some lifestyle intervention programs, but lower than in others [40-42]. More than $75 \%$ of participants who enrolled into the program 
Table 6 Metabolic outcomes: changes from baseline to six and thirty weeks ${ }^{\text {a }}$

\begin{tabular}{|c|c|c|c|c|c|}
\hline \multirow[t]{2}{*}{ Factor } & \multirow[t]{2}{*}{ Units } & \multicolumn{2}{|c|}{$\begin{array}{l}\text { Change at week six } \\
\qquad(\mathrm{N}=392)\end{array}$} & \multicolumn{2}{|c|}{$\begin{array}{l}\text { Change at week thirty } \\
(\mathrm{N}=295)\end{array}$} \\
\hline & & Mean \pm SD & $P$ value $^{\mathrm{b}}$ & Mean \pm SD & P value ${ }^{b}$ \\
\hline \multirow[t]{2}{*}{ Glucose } & $(\mathrm{mg} / \mathrm{dL})$ & $-6.3 \pm 24.3^{c}$ & $<0.001$ & $-4.5 \pm 29.6^{e}$ & 0.009 \\
\hline & $(\mathrm{mmol} / \mathrm{L})$ & $-0.35 \pm 1.35$ & & $-0.25 \pm 1.64$ & \\
\hline \multirow[t]{2}{*}{ Triglycerides } & $(\mathrm{mg} / \mathrm{dL})$ & $-27.7 \pm 53.8$ & $<0.001$ & $-26.4 \pm 58.5$ & $<0.001$ \\
\hline & $(\mathrm{mmol} / \mathrm{L})$ & $-0.31 \pm 0.61$ & & $-0.30 \pm 0.66$ & \\
\hline \multirow[t]{2}{*}{ Cholesterol } & $(\mathrm{mg} / \mathrm{dL})$ & $-21.7 \pm 25.9$ & $<0.001$ & $-9.0 \pm 29.5$ & $<0.001$ \\
\hline & $(\mathrm{mmol} / \mathrm{L})$ & $-0.56 \pm 0.67$ & & $-0.23 \pm 0.76$ & \\
\hline \multirow[t]{2}{*}{$\overline{\mathrm{HDL}}$} & $(\mathrm{mg} / \mathrm{dL})$ & $-2.0 \pm 6.8$ & $<0.001$ & $3.7 \pm 8.4$ & $<0.001$ \\
\hline & $(\mathrm{mmol} / \mathrm{L})$ & $-0.05 \pm 0.17$ & & $0.10 \pm 0.22$ & \\
\hline \multirow[t]{2}{*}{$\overline{\mathrm{LDL}}$} & $(\mathrm{mg} / \mathrm{dL})$ & $-14.3 \pm 21.6^{d}$ & $<0.001$ & $-7.9 \pm 25.1$ & $<0.001$ \\
\hline & $(\mathrm{mmol} / \mathrm{L})$ & $-0.37 \pm 0.56$ & & $-0.20 \pm 0.65$ & \\
\hline HgbA1c & (\%) & $\mathrm{N} / \mathrm{A}$ & $\mathrm{N} / \mathrm{A}$ & $-0.2 \pm 0.6^{f}$ & $<0.001$ \\
\hline \multirow[t]{2}{*}{ Insulin } & (microU/dL) & $-4.4 \pm 9.7$ & $<0.001$ & $-3.8 \pm 11.0$ & $<0.001$ \\
\hline & $(\mathrm{pmol} / \mathrm{L})$ & $-30.7 \pm 67.4$ & & $-26.6 \pm 76.4$ & \\
\hline \multirow[t]{2}{*}{ US-CRP } & $(\mathrm{mg} / \mathrm{mL})$ & $-1.4 \pm 6.4$ & $<0.001$ & $-0.9 \pm 4.8$ & 0.012 \\
\hline & $(\mathrm{nmol} / \mathrm{L})$ & $-11.9 \pm 54.0$ & & $-7.3 \pm 40.2$ & \\
\hline
\end{tabular}

Abbreviations: HDL, high-density lipoprotein cholesterol; LDL, low-density lipoprotein cholesterol; HgbA1c, hemoglobin A1c; US-CRP, ultra sensitive c-reactive protein. N/A, no required measurement at six weeks.

${ }^{a} \mathrm{~N}=250,173$ for insulin and $\mathrm{N}=270,198$ for US-CRP since neither measured before June 2009.

${ }^{b} P$ value from the paired t-test, significant if $P<0.025$.

c, d, e, f indicate $9,1,3$, and 24 missing data points, respectively.

were selected by their employers on the basis that they had at least one of the chronic conditions and frequently included those who made little health improvements after participating in standard disease management programs. No pre-enrollment evaluation was conducted to ascertain whether potential participants were considering making lifestyle changes and whether they could count on support of their spouses

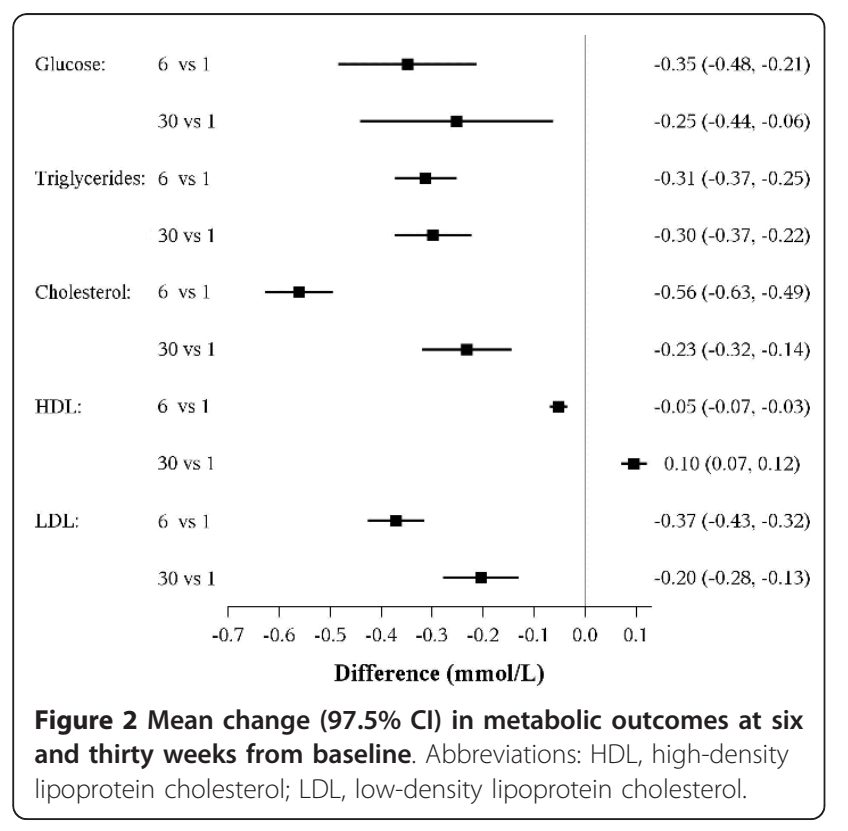

and families. Local self-insured employers paid in full the costs of the program for their participants (with exception of 26 participants who paid $20 \%$ of the costs). Participants were not penalized if they missed the classes and no financial incentives (besides paying for the program itself) were provided to them to attend the classes. It is possible that the attendance at week 30 follow up would have been better if some of these factors were considered and follow up visits were more frequent, as evidenced by changes to the program (for example, shorter Immersion phase of 4 weeks instead of original 6 weeks has decreased spacing between the visits, the longest being now 2 months instead of 3 months) we made (our subsequent data not reported here). Adherence to lifestyle interventions seems to increase with multiple follow-up visits [43].

This study has several weaknesses. Pre-post type of study is not suitable to establish causality and assess how much of the observed changes are specifically due to the program. A randomized clinical trial would be needed for that purpose. However, implementation of a comprehensive lifestyle intervention in a randomized fashion is hampered by preferences of participants (those who prefer to engage in lifestyle improvement activities and those who don't) and may suffer from crossover problems [37]. Some of the observed changes could have been due to the placebo effect and possibly some other unidentified factors, not just to the participation in the lifestyle program per se. 
Table 7 Relationship between baseline conditions and weight change $(\mathbf{k g})$ at 6 and 30 weeks

\begin{tabular}{|c|c|c|c|c|c|}
\hline Factor & Levels & $\mathrm{N}$ & Mean \pm SD & $\begin{array}{c}\text { Difference in } \\
\text { means }(95 \% \mathrm{Cl})^{\mathrm{c}}\end{array}$ & $P$ value $^{c}$ \\
\hline \multicolumn{6}{|l|}{ At 6 weeks $^{\text {a }}$ : } \\
\hline \multirow[t]{2}{*}{ Diabetes } & Yes & 292 & $-3.9 \pm 2.7$ & $-0.11(-0.72,0.50)$ & 0.73 \\
\hline & No & 112 & $-3.7 \pm 2.5$ & & \\
\hline \multirow[t]{2}{*}{ Hyperlipidemia } & Yes & 243 & $-3.8 \pm 2.6$ & $-0.01(-0.51,0.54)$ & 0.96 \\
\hline & No & 161 & $-3.8 \pm 2.8$ & & \\
\hline \multirow[t]{2}{*}{ Hypertension } & Yes & 254 & $-3.9 \pm 2.7$ & $0.04(-0.49,0.57)$ & 0.88 \\
\hline & No & 150 & $-3.7 \pm 2.6$ & & \\
\hline \multirow[t]{2}{*}{ Metabolic syndrome } & Yes & 234 & $-4.3 \pm 2.7$ & $-0.57(-1.13,-0.01)$ & 0.048 \\
\hline & No & 164 & $-3.2 \pm 2.3$ & & \\
\hline \multirow[t]{2}{*}{ Obesity (BMI > 30) } & Yes & 324 & $-4.2 \pm 2.7$ & $-1.61(-2.26,-0.95)$ & $<0.001$ \\
\hline & No & 80 & $-2.3 \pm 1.9$ & $-0.64(-1.24,-0.05)^{d}$ & 0.033 \\
\hline \multicolumn{6}{|l|}{ At 30 weeks $^{\text {b: }}$} \\
\hline \multirow[t]{2}{*}{ Diabetes } & Yes & 176 & $-6.4 \pm 6.6$ & $1.22(-0.91,3.35)$ & 0.26 \\
\hline & No & 67 & $-7.7 \pm 7.7$ & & \\
\hline \multirow[t]{2}{*}{ Hyperlipidemia } & Yes & 151 & $-6.1 \pm 6.7$ & $1.51(-0.36,3.39)$ & 0.11 \\
\hline & No & 92 & $-7.9 \pm 7.0$ & & \\
\hline \multirow[t]{2}{*}{ Hypertension } & Yes & 155 & $-6.7 \pm 7.1$ & $0.32(-1.60,2.22)$ & 0.74 \\
\hline & No & 88 & $-6.9 \pm 6.6$ & & \\
\hline \multirow[t]{2}{*}{ Metabolic syndrome } & Yes & 135 & $-7.3 \pm 8.1$ & $-0.69(-2.63,1.25)$ & 0.48 \\
\hline & No & 104 & $-6.0 \pm 4.9$ & & \\
\hline \multirow[t]{2}{*}{ Obesity $(\mathrm{BMI}>30)$} & Yes & 185 & $-7.6 \pm 7.4$ & $-3.69(-5.86,-1.52)$ & $<0.001$ \\
\hline & No & 58 & $-4.2 \pm 4.1$ & $-2.1(-4.08,-0.12) \mathbf{d}^{\mathbf{d}}$ & 0.038 \\
\hline
\end{tabular}

${ }^{a}$ Multivariable model $(\mathrm{N}=398)$ including all five conditions in table plus age, gender, payment options.

${ }^{\mathrm{b}}$ Multivariable model $(\mathrm{N}=239)$ including all five conditions in table plus age, gender, payment options.

"Multivariable model results; significant if $P<0.025$; difference in mean change for "Yes" minus "No".

${ }^{d}$ Difference in mean percent change from baseline.

Less than $25 \%$ of participants paid out of their pocket for participation in the program. This self-selected group of people who could financially afford the program and were able to accommodate their schedules during the first six weeks of the Immersion Phase are clearly not representative of the general population. For example, personality traits differ between obese persons who enroll and those who do not enroll in comprehensive lifestyle intervention programs [44]. Also, there was a bias in selection of participants by their employers to enroll in Lifestyle 180 as discussed above.

Because of only 6 months of intervention, inferences about long-term effectiveness cannot be made. Longer term data are needed to demonstrate that beneficial lifestyle changes are sustainable for such a large percentage of participants. An additional weakness of this study is that we did not evaluate adherence to the program and therefore we were unable to correlate the degree of adherence to the lifestyle program with changes in risk factors and to identify aspect(s) of lifestyle changes that are the most important for good outcomes. The outcomes data are reported for a heterogeneous group of participants and a subgroup analysis would be needed for better evaluation of chronic disease-specific outcomes. In addition, one might argue that significant improvements in lipids, glucose and inflammation markers could be the result of increased use of medications rather than participation in lifestyle intervention. While the cost-effectiveness analysis of the Lifestyle 180 program (including changes in pharmaceuticals) is in progress (manuscript in preparation), as shown in Table 8 , for every newly started medication or one with increased dose, 3.3 medications were stopped, reduced in dose or avoided. This suggests that a spectrum of significant and beneficial biometric and biomarker improvements

Table 8 Medication changes at 30 weeks

\begin{tabular}{lcccc}
\hline & Diabetes & Hyperlipidemia & Hypertension & Total \\
\hline Stopped & 33 & 39 & 79 & 151 \\
Decreased & 47 & 12 & 30 & 89 \\
Avoided & 3 & 18 & 3 & 24 \\
Total & $\mathbf{8 3}$ & $\mathbf{6 9}$ & $\mathbf{1 1 2}$ & $\mathbf{2 6 4}$ \\
Started & 12 & 14 & 36 & 62 \\
Increased & 9 & 3 & 6 & 18 \\
Total & $\mathbf{2 1}$ & $\mathbf{1 7}$ & $\mathbf{4 2}$ & $\mathbf{8 0}$ \\
\hline
\end{tabular}


occurred among participants who used less, not more medications.

\section{Conclusions}

Participation in a comprehensive Lifestyle 180 program results in significant and rapid, as well as clinically and biologically relevant improvements in biometric and laboratory outcomes, including reduced need for medications, for adults with multiple chronic conditions. Further follow up is needed to see if these beneficial changes are sustained.

\section{List of Abbreviations}

LDL: low-density lipoprotein cholesterol; HDL: high-density lipoprotein cholesterol; HgbA1c: hemoglobin A1c; US - CRP: ultra sensitive C-reactive protein; SBP: systolic blood pressure.

\section{Acknowledgements}

We are grateful to all participants in the Lifestyle 180 program and the companies that sponsored their participation. We also thank the two anonymous reviewers for their insightful comments and suggestions that helped improve this communication. This study was supported by the Wellness Institute of the Cleveland Clinic.

Lifestyle 180 Personnel

Nutrition: Kristin Kirkpatrick, MS, RD, LD, Berri L. Burns, RD, LD, Lori Assad RD, LD; Cooking: James D. Perko CEC, AAC; Michelle Bartoul-Mangan, BA; Yoga: Judi Bar, E-500 RYT, CYT, RM; Chris Keller, 500-RYT, CYT, Linda Baron, 500-RYT, CYT; Behavioral Health: Jane Pernotto Ehrman, MEd, CHES, David Phillips, MEd, Linna F. Lippke, MA, Jerome Kiffer, MA; Exercise: Fredina Weems, MR, BA/Ed,ACSM,HDCl,AFAA, Charles Walter, MA, Tracy Hafan, MS, Jessica Mospan MEd, ACSM, Christine Volk MEd, ACSM, Renee Goldstein MEd, ACSM, Dave Cannon, MA, RCEP, CSCS; Case Managers: Alison Kobs, RN, BSN, Natalie Rudd, RN, BSN; Mary Beth Schneeberger RN, BSN, Carol Longville, RN, BSN; Database: Jonathan Doyle, MCS, Gina Gendy, MD; Enrollment: Barbara A. Blankfeld; Administrative support: Nabil Gabriel, MBA, Regina Chandler, Emily E. Fox, MBA, MSSA, LSW, Kathleen M. Chambers, Jackie Frey.

\section{Author details}

'Wellness Institute, Cleveland Clinic, 1950 Richmond Road, TR2-341, Lyndhurst, OH 44124, USA. ${ }^{2}$ Quantitative Health Sciences, Cleveland Clinic, 9500 Euclid Avenue, Cleveland, OH 44195, USA. ${ }^{3}$ Outcomes Research, Cleveland Clinic, 9500 Euclid Avenue, Cleveland, OH 44195, USA.

\section{Authors' contributions}

All authors read and approved the final manuscript. Study concept and design: EWR, MFR, LS; Acquisition of data: EWR, MG; Statistical analysis and interpretation of data: EM, DY, MFR, MG; Drafting of the manuscript: EWR, $M G, E M, M F R, D Y ;$ Critical revision of the manuscript for important intellectual content: MFR, LS, MG; Administrative, technical, or material support: MFR, EWR.

\section{Competing interests}

The authors have no potential conflicts of interest, including specific financial interests and relationships and affiliations relevant to the subject matter or materials discussed in the manuscript.

Received: 5 July 2011 Accepted: 23 November 2011

Published: 23 November 2011

\section{References}

1. Willett WC: Balancing Life-Style and Genomics Research for Disease Prevention. Science 2002, 296:695-698.

2. World Health Organization: Diet, Nutrition and the Prevention of Chronic Diseases. WHO Technical Report Series 9162003.

3. Ford ES, Bergmann MM, Kröger J, Schienkiewitz A, Weikert C, Boeing H: Healthy living is the best revenge: findings from the European
Prospective Investigation Into Cancer and Nutrition-Potsdam study. Arch Intern Med 2009, 169(15):1355-62.

4. American College of Preventive Medicine: Lifestyle Medicine-Evidence Review. 2009 [http://www.acpm.org/lifestyleMedicine.htm], Accessed July 4, 2010.

5. Ornish D, Scherwitz LW, Billings JH, Brown SE, Gould KL, Merritt TA, et al: Intensive Lifestyle Changes for Reversal of coronary heart disease. JAMA 1998, 280(23):2001-7.

6. Silberman A, Banthia R, Estay IS, Kemp C, Studley J, Hareras D, Ornish D: The effectiveness and efficacy of an intensive cardiac rehabilitation program in 24 sites. Am J Health Promot 2010, 24(4):260-6.

7. Kalter-Leibovici O, Younis-Zeidan N, Atamna A, Lubin F, Alpert G, Chetrit A, et al: Lifestyle intervention in obese Arab women: a randomized controlled trial. Arch Intern Med 2010, 170(11):970-6.

8. Sullivan S, Samuel S: Effect of short-term Pritikin diet therapy on the metabolic syndrome. J Cardiometab Syndr 2006, Fall; 1(5):308-12.

9. Albu JB, Heilbronn LK, Kelley DE, Smith SR, Azuma K, Berk ES, Pi-Sunyer FX, Ravussin E: Look AHEAD Adipose Research Group. Metabolic changes following a 1-year diet and exercise intervention in patients with type 2 diabetes. Diabetes 2010, 59(3):627-33, Epub 2009 Dec 22.

10. Hyman MA, Ornish D, Roizen M: Lifestyle medicine: treating the causes of disease. Altern Ther Health Med 2009, 15(6):12-4.

11. National Cholesterol Education Program (NCEP) Expert Panel on Detection, Treatment of High Blood Cholesterol in Adults (Adult Treatment Panel III): Third Report of the National Cholesterol Education Program (NCEP) Expert Panel on Detection, Evaluation, and Treatment of High Blood Cholesterol in Adults (Adult Treatment Panel III) final report. Circulation 2002, 106(25):3143-421.

12. Clinical Guidelines on the Identification, Evaluation, and Treatment of Overweight and Obesity in Adults-The Evidence Report. National Institutes of Health. Obes Res 1998, 6(Suppl 2):51S.

13. American Diabetes Association: Diagnosis and Classification of Diabetes Mellitus. Diabetes Care 2011, 34:S62-S69.

14. The IDF consensus worldwide definition of the metabolic syndrome. IDF 2006 [http://www.idf.org/webdata/docs/MetS_def_update2006.pdf].

15. Harris MOR, Flomo D: Changing and Adhering to Lifestyle Change: What are the Keys? American Journal of Lifestyle Medicine 2007, 1(3):214-219.

16. Serra-Majem L, Roman B, Estruch R: Scientific evidence of interventions using the Mediterranean diet: a systematic review. Nutr Rev 2006, 64(2 Pt 2):S27-47.

17. de Kok TM, de Waard P, Wilms LC, van Breda SG: Antioxidative and antigenotoxic properties of vegetables and dietary phytochemicals: the value of genomics biomarkers in molecular epidemiology. Mol Nutr Food Res 2010, 54(2):208-17.

18. Wing RR, Goldstein MG, Acton KJ, Birch LL, Jakicic JM, Sallis JF Jr, et al: Behavioral science research in diabetes: lifestyle changes related to obesity, eating behavior, and physical activity. Diabetes Care 2001, 24(1):117-23.

19. Murphy CT, McCarroll SA, Bargmann Cl, Fraser A, Kamath RS, Ahringer J, $\mathrm{Li} \mathrm{H}$, Kenyon C: Genes that act downstream of DAF-16 to influence the lifespan of Caenorhabditis elegans. Nature 2003, 424(6946):277-83, Epub 2003 Jun 29.

20. Lee SJ, Murphy CT, Kenyon C: Glucose shortens the life span of C. elegans by downregulating DAF-16/FOXO activity and aquaporin gene expression. Cell Metab 2009, 10(5):379-91.

21. Buckland G, Bach A, Serra-Majem L: Obesity and the Mediterranean diet: a systematic review of observational and intervention studies. Obes Rev 2008, 9(6):582-93, Epub 2008 Jun 10.

22. U.S. Department of Health and Human Services. 2008 Physical Activity Guidelines for Americans. Hyattsville, MD: U.S. Department of Health and Human Services; 2008 [http://www.health.gov/paguidelines], Accessed July 26, 2010.

23. Tresierras MA, Balady GJ: Resistance training in the treatment of diabetes and obesity: mechanisms and outcomes. J Cardiopulm Rehabil Prev 2009, 29(2):67-75.

24. Roizen MF, Hafen T, Armour LA: The RealAge workout: maximum health, minimum work. New York: Collins; 1 2006, xv, 216.

25. Bravata DM, Smith-Spangler C, Sundaram V, Gienger AL, Lin N, Lewis R, Stave CD, Olkin I, Sirard JR: Using pedometers to increase physical activity and improve health: a systematic review. JAMA 2007, 298(19):2296-304.

26. Roizen MF, Oz M: You, on a diet: the owner's manual for waist management. Rev. and expanded. New York: Free Press; 2009. 
27. Nakao M, Fricchione $G$, Myers $P$, Zuttermeister $P C$, Baim $M$, Mandle $C L$, Medich C, Wells-Federman CL, Martin Arcari P, Ennis M, Barsky AJ, Benson $\mathrm{H}$ : Anxiety is a good indicator for somatic symptom reduction through behavioral medicine intervention in a mind/body medicine clinic. Psychother Psychosom 2001, 70(1):50-7.

28. Stevens J, Truesdale KP, McClain JE, Cai J: The definition of weight maintenance. Int J Obes (Lond) 2006, 30(3):391-9.

29. Frattaroli J, Weidner G, Dnistrian AM, Kemp C, Daubenmier JJ, Marlin RO, Crutchfield L, Yglecias L, Carroll PR, Ornish D: Clinical events in prostate cancer lifestyle trial: results from two years of follow-up. Urology 2008, 72(6):1319-23.

30. Dattilo AM, Kris-Etherton PM: Effects of weight reduction on blood lipids and lipoproteins: a meta-analysis. Am J Clin Nutr 1992, 56(2):320-8.

31. Nam BH, Kannel WB, D'Agostino RB: Search for an optimal atherogenic lipid risk profile: from the Framingham Study. Am J Cardiol 2006, 97(3):372-5.

32. Katcher HI, Hill AM, Lanford JL, Yoo JS, Kris-Etherton PM: Lifestyle approaches and dietary strategies to lower LDL-cholesterol and triglycerides and raise HDL-cholesterol. Endocrinol Metab Clin North Am 2009, 38(1):45-78.

33. Dattilo AM, Kris-Etherton PM: Effects of weight reduction on blood lipids and lipoproteins: a meta-analysis. Am J Clin Nutr 1992, 56(2):320-8.

34. Poobalan A, Aucott L, Smith WC, Avenell A, Jung R, Broom J, Grant AM: Effects of weight loss in overweight/obese individuals and long-term lipid outcomes-a systematic review. Obes Rev 2004, 5(1):43-50.

35. Bayturan O, Tuzcu EM, Lavoie A, Hu T, Wolski K, Schoenhagen P, Kapadia S, Nissen SE, Nicholls SJ: The metabolic syndrome, its component risk factors, and progression of coronary atherosclerosis. Arch Intern Med 2010, 170(5):478-84.

36. da Luz PL, Favarato D, Faria-Neto JR Jr, Lemos P, Chagas AC: High ratio of triglycerides to $\mathrm{HDL}$-cholesterol predicts extensive coronary disease. Clinics (Sao Paulo) 2008, 63(4):427-32.

37. Ornish D: Avoiding revascularization with lifestyle changes: The Multicenter Lifestyle Demonstration Project. Am J Cardiol 1998, 82(10B):72T-76T.

38. Nathan C, Ding A: Nonresolving inflammation. Cell 2010, 140(6):871-82

39. Beavers KM, Nicklas BJ: Effects of lifestyle interventions on inflammatory markers in the metabolic syndrome. Front Biosci (Schol Ed) 2011, 3:168-77.

40. Lim S, Norman R, Clifton P, Noakes M: The effect of comprehensive lifestyle intervention or metformin on obesity in young women. Nutr Metab Cardiovasc Dis 2011, 21(4):261-8.

41. Iqbal N, Vetter ML, Moore RH, Chittams JL, Dalton-Bakes CV, Dowd M, Williams-Smith C, Cardillo S, Wadden TA: Effects of a Low-intensity Intervention That Prescribed a Low-carbohydrate vs. a Low-fat Diet in Obese, Diabetic Participants. Obesity (Silver Spring) 2010, 18(9):1733-8.

42. Murawski ME, Milsom VA, Ross KM, Rickel KA, DeBraganza N, Gibbons LM, Perri MG: Problem solving, treatment adherence, and weight-loss outcome among women participating in lifestyle treatment for obesity. Eat Behav 2009, 10(3):146-51.

43. Fappa E, Yannakoulia M, Pitsavos C, Skoumas I, Valourdou S, Stefanadis C: Lifestyle intervention in the management of metabolic syndrome: could we improve adherence issues? Nutrition 2008, 24(3):286-91, Epub 2008 Jan 16.

44. Sullivan S, Cloninger CR, Przybeck TR, Klein S: Personality characteristics in obesity and relationship with successful weight loss. Int J Obes (Lond) 2007, 31(4):669-74.

doi:10.1186/1743-7075-8-83

Cite this article as: Ricanati et al: Mitigating preventable chronic

disease: Progress report of the Cleveland Clinic's Lifestyle 180 program. Nutrition \& Metabolism 2011 8:83.

\section{Submit your next manuscript to BioMed Central and take full advantage of:}

- Convenient online submission

- Thorough peer review

- No space constraints or color figure charges

- Immediate publication on acceptance

- Inclusion in PubMed, CAS, Scopus and Google Scholar

- Research which is freely available for redistribution

Submit your manuscript at www.biomedcentral.com/submit
Biomed Central 